\title{
Mood of space station partners lifts
}

Paris, Washington and Tokyo. Space station supporters were confident of winning the support of the US House of Representatives in a crucial vote due yesterday on President Clinton's revised design proposal for a version of the project which will cost $\$ 10.5$ billion over five years.

But after the president announced his own support for the project last week, it emerged that no detailed work has been done on the proposed compromise design

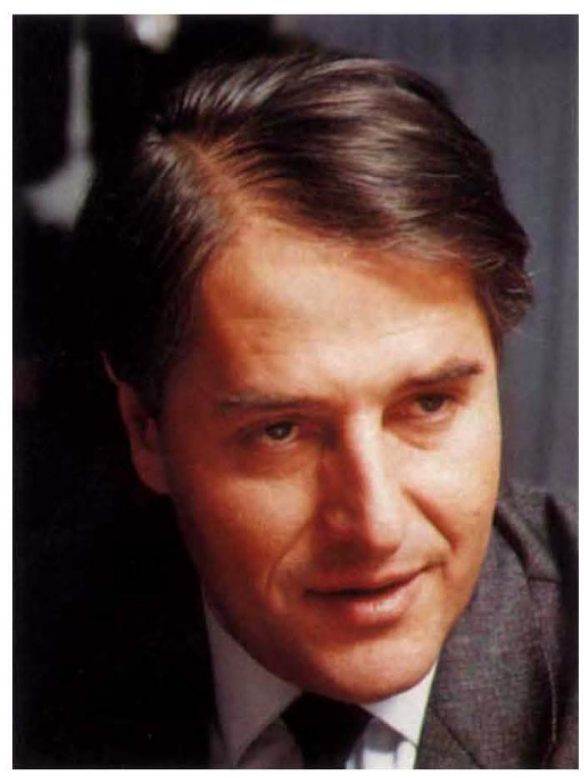

Luton: open to "a redefinition of the international space station".

which, the White House says, will reconcile aspects of the two modular space stations options A and B - suggested by a NASA redesign process, while costing slightly less than either one.

"I sometimes wonder if they've sort of fuzzed it up to try and keep me happy", says George Brown (Democrat, California), chairman of the House Science, Space and Technology committee and salesman-in-chief for the space station in Congress. Brown admits it will be hard to sell a compromise that remains so ill-defined. "It would be better if we had the information, but we won't get it for two or three months", he says. However, as they canvassed for support late last week, advocates of the station were confident of winning yesterday's vote.

The White House has also deferred judgement on which orbital inclination the space station should be launched into - the 51.6 degrees which would suit Russian launchers, or the 28.2 degrees for which the US space shuttle is designed. Brown has even floated the idea of a 'compromise' orbit between the two: the Russian orbit is constricted by its concern about flying over China, which might be readily eased.

What is clear is that Option C, the non- modular, 'tin can' option thought to be favoured by NASA administrator Dan Goldin has been ditched, much to the relief of the international partners. The partners are even more relieved that Clinton has given a space station design his full backing, and are now confident that the project can regain some of the momentum it has lost in the past few months.

"We couldn't have hoped for a better outcome," says Lanfranco Emiliani, head of the European Space Agency's ECU 2.4 billion input to the programme.

Clinton's endorsement of a space station combining elements of options $\mathrm{A}$ and $\mathrm{B}$ has allayed ESA's fears for the project's future. ESA is also pleased that Clinton deferred a decision on the orbit. The president's special advisory panel on the station redesign, chaired by Dr Charles M. Vest, president of the Massachusetts Institute of Technology, had recommended the higher orbit. But ESA was worried that launching its module into this orbit would require using the Russian Proton rocket, a competitor of Ariane.

Clinton's decision has restored some measure of confidence among the space lobby in Europe, where support for the station has been crumbling. "There is now the political will to continue with the space station," says Klaus Berge, director of the German space programme. Whether there is a financial way is another matter. Italy, for example, has already said that it cannot afford to meet the commitments it made in Granada last November (see Nature 360, 199; 1992).

Continued support for the station in Europe is likely to be forthcoming only if the present ad hoc collaboration is transformed into a truly international project. The stumbling block to a ménage à trois between Europe, Russia and the US is that all three are competitors - for example in the commercial satellite launch market (sec below).
And while Europe and the United States make much of their efforts to save Russian space competencies in public, officials admit in private that both are jealously competing for access to Russian technology.

Russian prime minister Viktor Chernomydrin is likely to discuss greater Russian participation in the space station when he meets US vice-president AI Gore next month. ESA objects to any broader Russian role now, but Jean-Marie Luton, director general of ESA, says that he is open to "a redefinition of the international space station" if this is "acceptable to all the present partners."

Relief at the demise of option C is shared by Japan. According to Junji Yoshihara, director of the office of space utilization of the Science and Technology Agency, the government agency funding Japan's space station programme, Japan would be happier with $B$ but they can live with $A$ as well.

Japan is already committed to spend half of the $¥ 310$ billion ( $\$ 2.95$ billion) it plans to spend on its contribution to the station. In addition, it has spent $¥ 4.6$ billion so far on a new control centre for the station in Tsukuba science city. Construction of the Japanese module is due to start this year. Yoshihara says that the agency had hoped to increase the budget for the station by $¥ 20$ billion next fiscal year (beginning 1 April) from this year’s $¥ 45.8$ billion. "But because of the redesign, the Ministry of Finance is asking 'if the United States can reduce its budget for the station why can't we?"”.

But Japanese officials recognize that, despite Clinton's commitment, the final decision will still rest with Congress, and that the station could still be dropped - a prospect for which they have prepared no contingency plans. Last week, they were continuing to warn of the dire consequences of such an outcome for international scientific collaboration.

Declan Butler, Colin Macilwain and David Swinbanks

\section{Launch wars}

Even as Europe, Russia and the United States discuss prospects for greater cooperation in the space station, all three are engaged in a bitter battle for a share of the commercial satellite launch market.

The United States and Europe are concerned that unless Russia's entry is regulated it could destabilize the market through what they see as 'dumping' - Russia can undercut by half the $\$ 62$-million price-tag of an Ariane launch. But the United States and Europe are divided over the rules of fair play: the United States accuses Europe of subsidizing Ariane, while ESA wants the United States to open up government contracts to foreign competition.

Independently of Europe, the United States this month agreed tariffs and quotas with Russia for the launch of US satellites using its Proton rocket (Lockheed has also agreed with the Krounitchev company to market Proton in the United States). Europe immediately accused the United States of manipulating events to destabilize Ariane as the market leader ( 50 per cent) while protecting its own Atlas, Titan and Delta launchers. But ESA has since made a similar agreement with the Russians.

D.B. 